\title{
The Reversal of Stock Market Trends as a Behavioral Bias: Evidence from Tunisian Stock Exchange
}

\author{
Hsini Mosbeh \\ Higher Institute of Commerce and Accountancy of Bizerte, Carthage University, Tunisia \\ E-mail: lahsinim@gmail.com
}

Kouki Mondher (Corresponding author)

Faculty of Economics and Management of Tunis, Tunis El Manar University, Tunisia

E-mail: koukimondher@yahoo.fr

Received: April 17, 2016 Accepted: May 2, 2016

doi:10.5296/ber.v6i2.9326 URL: http://dx.doi.org/10.5296/ber.v6i2.9326

\begin{abstract}
This paper examines the behavioral bias in Tunisia, a country with a small stock market in terms of capital, but surprisingly dynamic in comparison to other emerging markets. Our study is consistent with Jegadeesh \& Titman (1993)' approach as presented to highlight an analysis of such reversal phenomena of portfolio returns, and provides explanatory factors to the so-called market trends reversal. The empirical investigation is based on a weekly database for a period from January 2002 to January 2013 related to stock prices and index values of market capitalization (TUNINDEX). The empirical test demonstrates the existence of winner-loser phenomenon in accordance with over-reaction hypothesis stating that portfolios with the worst past performance outperform, during the subsequent periods, those having produced best past performance and vice versa.
\end{abstract}

Keywords: Behavioral bias, Reversal, Stock market trend, Momentum effect

JEL Classification: G11, G12, G14, G15

\section{Introduction}

Financial market anomalies known as an empirical pattern in stock market that are not predicted by the standard equilibrium model (e.g, capital asset pricing model). Much of the earlier studies document that various anomalies remain without explanation; they seem to disappear, reverse or attenuate. Jegadeesh and Titman (1993) show that the winner assets 
during the three to twelve months are more likely to continue behaving winner through the three and twelve subsequent months, reporting consequently a momentum bias over the short period. Fama (1998) conclude that tendency not to react (under-reaction) to certain firms' news is also frequent as the tendency to overreact (over-reaction) to these news.

According to Lee et al. (1991), Rowenhorst (1999), Shiller (2000b), George \& Hwang (2004), Lowenstein \& Willard (2006), Titman \& Daniel (2008), Gervais et al. (2011) Bertrand \& Morse (2012), Buraschi et al. (2014), investors do not react properly to the information they receive. Indeed, they commit cognitive errors that can be profitably exploited by other operators. This incorrect reaction towards information includes under-reaction, over-reaction, momentum, bubbles and crashes.

The concept of momentum in stock markets is defined as the way the prices can fluctuate in the market. In this sense, when the market is in a phase of upward or downward acceleration, momentum increases and consequently the price trend persists. The zero crossing is representative of a reversal trend, and constitutes thus a signal to buy / sell [Delong et al. (1990), De Bondt \& Thaler (1985), Lee et al. (1991), Orlean (1994), Sherbina (2004), Ang et al. (2005) Gervais et al. (2011), Alti \& Lock (2014)]. Furthermore, other researchers mainly Barberis et al. (1998), Hong \& Stein (1999), Jegadeesh \& Titman (2001a, 2001b) have examined the hypothesis that the momentum effect is attributed to operators' slowness when reacting to good news. The idea underlying these stock market anomalies is that securities have performed well over the last twelve months tend to beat the market over the next twelve months. Evoking this behavioral bias fact reveal a phenomenon of persistence of winners, at least in the short term, synonymous securities with known abnormal returns during the six to twelve months tend to do better than average in the six to twelve months. Baker \& Wurgler (2006), Gervais et al. (2011), Bazak \& Makarov (2014) considered that even mutual funds and exchange-traded funds are characterized by a momentum effect. They postulate that the funds that have performed very well during the last year would tend to beat the index during the next twelve months. Conversely, securities against a known performance during the past twelve months have high propensities to repeat the poor performance during the next twelve months. Following Daniel et al. (1998) if there is a momentum effect of stock prices in the short term (one to two years), there is however a long term reversal effect (three to five years). This observation derives its essence from the fact that shares that made significant gains in the last three to five years tend to exhibit a reversal in yields and consequently to produce returns below average during the next three to five years.

The remainder of the paper is organized as follows. The next section provides framework of theoretical background and evidence according to the prior empirical tests. The third section presents the data and methodology. The empirical results are reported in section 4 and the least section concludes the paper.

\section{Literature Review}

\subsection{The Momentum Effect Causes}

Faced with an abnormality such as the momentum effect, many studies have analyzed this 
phenomenon and have therefore advanced the generating causes of this. Rowenhorst (1998) postulates that securities enjoying a momentum effect are not more risky and volatile than others. In addition, it is not the size of the companies or their book value compared to their market price that explains this stock bias. Moreover, momentum effect is relatively independent of risk, beta, size, and valorization multiples. Likewise, Chan et al. (1996) note that financial markets are not fully efficient while incorporating such a new public information in stock prices. Thus, it often takes more than a year before the firm recovery; the profitability improvement and its resumed earnings growth are eventually reflected in the share price.

Jegadeesh and Titman (1993) advanced the idea that investors are supposed to revise their beliefs according to Bayes' theorem. Moreover, the use of simple heuristics in certain situations led them to make bad decisions and they do not revise properly their opinions. This can be explained by the fact that investors tend to consider a small series of events as representative of the events series distribution. Such behavior is highlighted when a company announces for several years higher earnings than expected, then, investors have a tendency to extrapolate these good results in the following years and buy accordingly these considered securities. De Bondt \& Thaler (1985), Daniel et al. (1998) argue that most operators are inclined to overestimate their ability to make good decisions. This is known as the overconfidence bias, which is reinforced by the fact that one attributes to himself more easily the positive consequences issuing such a decision, whereas negative consequences are rejected on external circumstances (self attribution bias). Thus, operators have the tendency to believe that not only their information is better than those of others operating over the market but also to overestimate their ability to make the right investments.

In the same context, the model of Barberis et al. (1998) is based on two assumptions that the investor would exercise such a conservatism excess when updating his models and his expectations (conservatism bias), Besides, investor cognitive functioning would lead him to do extrapolation based on the latest information at the expense of other relevant financial data (representative heuristic). The first assumption results in a short-term under-reaction that explains the profitability of momentum strategies, while the second hypothesis would support the theory of price mean reversion in a long-term. Daniel et al. (2098), Lewellen (2002), Fong (2005) Gervais et al. (2011) Bazak \& Makarov (2014) note that when investors undertake costs when looking for information so they overestimate the quality of this information. Thus, when new information (earnings announcements) come to market, revising their expectations is not alike as it confirm or not their private information. Kahneman \& Tverky (1979) postulate that when a security has good performances, then investors are less sensitive to future bad news. They consider therefore this asset as being less risky than before and update future flows at a lower rate, increasing their price earnings ratio(PER). Conversely, a security having yet bad performances let them more sensitive to future bad news. They consider therefore this asset as riskier and update future flows at a higher rate that decreases their PER. These discount rate changes let securities more volatile than cash flows. Investor behavior also shows that securities with high valuation ratios have significant returns than those with smaller ratios. While operators prove to be risk averse in a 
gain position, they can also become risk takers after a series of good performances. This behavior is known as the house money effect.

\subsection{The Securities Past Performance And Investment Strategies}

The momentum or relative continuity in stock returns corresponds to the tendency of these securities having witnessed a good (bad) performance in the past to achieve a good (bad) performance in the future. Jegadeesh \& Titman (1993) postulate that investment strategies which involve the purchase of best performing securities during the previous three to twelve months(3-12months) and to sell short the worst performing ones during the same period, are profitable and generate accordingly a return of around $1 \%$ per month for the subsequent three to twelve months. Moreover, their investigation revealed the effect of buying past winner stocks and a sale of those behaving losers in the past, when referring to the series of returns

This result, corroborated by Fama \& French (1996), Albert \& Wang (1998), Chan et al. (1999), Jegadeesh \&Titman (2001), Gervais et al. (2011) Bazak \& Makarov (2014) for the United States, does also worth for developed markets namely Europe and Canada. A study of Bacmann \& Dubois (1999) conducted on the Swiss market showed abnormally high profitability for mimetic strategies known as momentum, for medium term (six to eighteen months). It goes alike for contrarian strategies for recomposed portfolios in short term (conservation of such a position from one week to one month) or even in long term (three to five years). Both types of strategies differ only in the reference period used for calculating the past profitability as well as the portfolio definition.

Rowenhorst (1999) argued, for twelve European countries, the phenomenon of the momentum effect initially observed in the United States. In the same vein, Chan et al. (1996) confirmed these results. They argue that several possible reasons for the persistence of the phenomenon, especially the under-reaction to changes in earnings forecasts, the positive feedback trading, and under-reaction to announcements of benefits. George \& Huang (2004), Leowenstein et al. (2005), Kogan et al. (2006), Zhang (2006) highlighted the danger of choosing equity funds, and particularly those who have done very well for five years. They assert that caution recommends betting including equity funds have generated excellent returns during the last twelve months, and keep them thereafter only one year. As for the funds that generated poor results, it is favourable to focus on funds whose horizon is a little longer, at least three years (Tversky \& Kahneman (1982), Jegadeesh \& Titman (1993), Zigler (2001), Durham et al. (2005)).

\section{Data and Methodology}

The momentum reflects the difference in price of a security for a given time interval. In this sense, the momentum known as the Relative Strength Index (RSI) measures prices' assessment for a given period. However, unlike the RSI, which is the ratio between prices' increases and fluctuations' set, momentum can analyze only prices' variations between the beginning and end of the study period. Thus, more this period is wide, the more the daily fluctuations tend to disappear. Similarly, when the momentum is above zero or its curve is 
rising, it indicates an upward trend. Furthermore, a buy signal is given as soon as the momentum exceeds zero, and vice versa when it drops below it triggers a sell signal (Rowenhorst (1998), Hong \& Stein (1999)). Jegadeesh \& Titman (1993) postulate that momentum is obtained by calculating day-by-day prices' difference of securities for a given time interval. The following formula shows how to calculate such a momentum of $\mathrm{x}$ days:

$$
\operatorname{Mom}_{(x \text { days })}=C_{t}-C_{t-x}
$$

Where $C_{t}$ is the price of day $t, C_{t-x}$ is the price $x$ days before. Thus, since the momentum follows securities' prices, it is up to the latter therefore to fluctuate more than the former does. The period can range from one day for extremely volatile securities to 200 days for very long-term transactions. The most used values are over a period of 12 to 25 days. In fact, more the momentum is high, the more the security is overbought. Conversely, more the momentum is lower, the more the security is oversold. However, it is prudent to wait for a signal confirmation by the prices since such a security can remain overbought or oversold during a given time interval. Jegadeesh \& Titman (1993) consider that a phenomenon long recognized in securities analysis is the cyclical nature of the increases and decreases. It is this cyclicality that momentum seeks to stand out. Thus, the momentum for 12 days is recognized as giving an enough cyclic result oscillating up and down regularly. Consequently, the trend can be anticipated to come from previous cycles.

The majority of studies developed on the international financial markets that deals with portfolios formation and classification to winner or loser portfolios by calculating abnormal returns are spread over a long period. Our empirical investigation consider a weekly database for the period ranging from January 2002 until January 2013. Returns for both securities and market are calculated for every Wednesday as a reference day. In the absence of such quotation that day, we take the correspondent price of Tuesday (the day before), if not, the price of the day after (Thursday). Once there is no trading or Tuesday or Thursday, then we resort to the adjustment by the simple moving average (order four) of the missing data:

$$
\mathrm{P}_{\mathrm{t}}=\left(\mathrm{P}_{\mathrm{t}-4}+\mathrm{P}_{\mathrm{t}-3}+\mathrm{P}_{\mathrm{t}-2}+\mathrm{P}_{\mathrm{t}-1}\right) / 4 \text {. }
$$

Our sample is consisted of ten (10) companies over a period of eleven years (11years) related to their stock prices and the index values of Tunisian market capitalization (Tunindex).

$$
\mathrm{R}_{\mathrm{it}}=\ln \left(\mathrm{C}_{\mathrm{t}} / \mathrm{C}_{\mathrm{i}, \mathrm{t}-1}\right)
$$

$\mathrm{C}_{\mathrm{t}}$ is the closing price of stock $\mathrm{i}$ during the week $\mathrm{t}, \mathrm{C}_{\mathrm{i}, \mathrm{t}-1}$ is the closing price of stock $\mathrm{i}$ during the week(t-1) We consider that $\mathrm{R}_{\mathrm{mt}}$ represents the weekly returns of the market index (Tunindex):

$$
\mathrm{Rmt}=\mathrm{In}\left(\mathrm{I}_{\mathrm{m}, \mathrm{t}} / \mathrm{I}_{\mathrm{m}, \mathrm{t}-1}\right)
$$




\section{Ml Macrothink}

Business and Economic Research

ISSN 2162-4860

2016, Vol. 6, No. 2

$\mathrm{I}_{\mathrm{mt}}$ market index Tunindex week $\mathrm{t}, \mathrm{I}_{\mathrm{m}, \mathrm{t}-1 \text { : }}$ market index Tunindex of the week $\mathrm{t}-1$, Once determining the returns $R_{i t}$ of stock $i$ and those of market $R_{m t}$ and for the sake to form our portfolios, we proceed to calculate the Average Residuals (AR) and then their Cumulative Average Residuals (CAR). The Average Residual of each stock i represents the difference between its return and market one: Average Residual:

$$
\mathrm{AR}_{\mathrm{t}}=\mathrm{R}_{\mathrm{it}}-\mathrm{R}_{\mathrm{mt}}
$$

The cumulative average residual of each security $i$ for each period of 36 weeks is the sum of AR in the first week until the 36th week: Cumulative Average Residual: CAR = cumulative average residuals

$$
C A R=\sum_{t=1}^{t=36} A R_{i, t}
$$

Note that the same procedure has to be redone fourteen times during the test period. It is important to point out in this framework that in order to state for the existence of a winner-loser phenomenon, we divided our study period into sub periods of 36 weeks and a portfolio is related to each sub period. To create winner and loser portfolios, it is important to mention that at the end of each period of 36 weeks $(36,72, \ldots, .360,396)$, a CAR is obtained, and then we proceeded to sort descending the CAR . This ranking allows to arbitrate winner stocks of those losers which will form our fifteen portfolios relatively to the fifteen sub-periods. After forming the various portfolios that were determined at the end of the formation period of 36 weeks, we conduct several tests within what we call the test period. Formation and identification of winners and losers portfolios is done through stocks that had expressed extreme residual returns into the formation periods. Generally, losers and winners portfolios are formed from extreme stocks according to their past performances.

The number of securities composing a portfolio does vary from one author to another, for instance: 35 extreme stocks chosen by De Bondt and Thaler (1985) , 10 extreme stocks chosen by Alonso and Rubio (1990), 5extreme stocks chosen by Rodrigues and Fructaso (2000), 3 extreme stocks chosen in our investigation related to the Tunisian stock market. After ranking the CAR in a descending order, the winner portfolio consists of the three stocks with the highest performance, while the loser portfolio is formed by the three stocks having the worst CAR. The CAR of each portfolio (w) and (L) during each 36-weeks test period is:

$$
C A R_{S}=\sum_{i=1}^{3} C A R_{s, i}
$$

Where $\mathrm{S}$ is the nature of the portfolio winner $(\mathrm{W})$ or loser $(\mathrm{L})$

\section{Empirical Results}

\subsection{Examination of Loser-Winner Effect}

The test period which follows the formation period consists of fourteen portfolios except the 
fifteenth portfolio corresponding to the initial formation period(table 1). During the second period (test period), we will test the evolution of CAR and this respectively winners and losers portfolios (PF1, PF15) determined during the first period

Table 1. Observation and detection of reversals winner \& Loser portfolios

\begin{tabular}{|c|c|c|c|c|c|c|}
\hline Portfolio & \multicolumn{2}{|c|}{ Formation period $C A R$} & \multicolumn{2}{|c|}{ Test period $C A R$} & \multirow{2}{*}{$\begin{array}{l}\text { Transformation phenomenon } \\
\text { WL }\end{array}$} & \multirow{2}{*}{$\begin{array}{l}\text { Detection } \\
\text { Exist } \\
\end{array}$} \\
\hline$P F 1$ & W & 0.289127 & -0.0862115 & $\mathrm{~L}$ & & \\
\hline & $\mathrm{L}$ & 0.1117926 & 0.08670031 & $\mathrm{~L}$ & LL & Do not exist \\
\hline \multirow[t]{2}{*}{$P F 2$} & $\mathrm{~W}$ & 0.0874379 & -0.478562 & $\mathrm{~L}$ & WL & Exist \\
\hline & $\mathrm{L}$ & -0.20610108 & -0.41600893 & $\mathrm{~L}$ & LL & Do not exist \\
\hline \multirow[t]{2}{*}{$P F 3$} & W & -0.09674974 & $-0,02201333$ & W & WW & Do not exist \\
\hline & $\mathrm{L}$ & -0.4516644 & $-0,1127013$ & W & LW & Exist \\
\hline \multirow[t]{2}{*}{ PF4 } & W & 0.02258053 & $-0,42669362$ & $\mathrm{~L}$ & WL & Exist \\
\hline & $\mathrm{L}$ & -0.19913907 & $-0,50484224$ & $\mathrm{~L}$ & LL & Do not exist \\
\hline \multirow[t]{2}{*}{$P F 5$} & W & -0.2747831 & $-0,23267728$ & $\mathrm{~L}$ & WL & Exist \\
\hline & $\mathrm{L}$ & -0.53526904 & $-0,23077566$ & W & LW & Exist \\
\hline \multirow[t]{2}{*}{ PF6 } & W & -0.085002 & $-0,74032633$ & $\mathrm{~L}$ & WL & Exist \\
\hline & $\mathrm{L}$ & -0.327868 & $-0,83314204$ & $\mathrm{~L}$ & LL & Do not exist \\
\hline \multirow[t]{2}{*}{$P F 7$} & W & -0.553847 & $-0,7354081$ & $\mathrm{~L}$ & WL & Exist \\
\hline & $\mathrm{L}$ & -0.982282 & $-0,30807216$ & W & LW & Exist \\
\hline \multirow[t]{2}{*}{$P F 8$} & W & -0.061891 & $-0,23401706$ & $\mathrm{~L}$ & WL & Exist \\
\hline & $\mathrm{L}$ & -0.7581589 & $-0,36733768$ & W & LW & Exist \\
\hline \multirow[t]{2}{*}{$P F 9$} & W & -0.07573862 & 0,22709402 & W & WW & Do not exist \\
\hline & $\mathrm{L}$ & -0.55567895 & $-0,09811062$ & W & LW & Exist \\
\hline \multirow[t]{2}{*}{ PF10 } & $\mathrm{W}$ & 0.198224506 & $-0,7517704$ & $\mathrm{~L}$ & WL & Exist \\
\hline & $\mathrm{L}$ & -0.1681864 & -0.80271792 & $\mathrm{~L}$ & LL & Do not exist \\
\hline \multirow[t]{2}{*}{$P F 11$} & $\mathrm{~W}$ & $-0,61661982$ & -0.62011479 & $\mathrm{~L}$ & WL & Exist \\
\hline & $\mathrm{L}$ & -0.921167155 & -0.77054482 & $\mathrm{~W}$ & LW & Exist \\
\hline \multirow[t]{2}{*}{$P F 12$} & $\mathrm{G}$ & -0.50171003 & 0.27519405 & W & WW & Do not exist \\
\hline & $\mathrm{L}$ & -0.77054482 & -0.00178617 & W & LW & Exist \\
\hline \multirow[t]{2}{*}{$P F 13$} & $\mathrm{G}$ & 0.27519405 & 0.03805047 & $\mathrm{~L}$ & WL & Exist \\
\hline & $\mathrm{L}$ & -0.00178617 & -0.2096479 & $\mathrm{~L}$ & LL & Do not exist \\
\hline \multirow[t]{2}{*}{$P F 14$} & $\mathrm{G}$ & 0.03805047 & 0.25942842 & W & WW & Do not exist \\
\hline & $\mathrm{L}$ & -0.20967479 & -0.31159883 & $\mathrm{~L}$ & LL & Do not exist \\
\hline \multirow[t]{2}{*}{$P F 15$} & $\mathrm{G}$ & 0.17798358 & 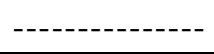 & -- & 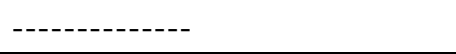 & 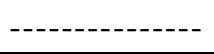 \\
\hline & $\mathrm{L}$ & -0.31159883 & 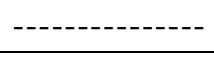 & -- & 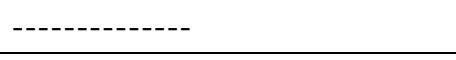 & ------'------- \\
\hline
\end{tabular}

After detecting such phenomena of returns reversal, we calculated the percentages of each observed phenomenon (Table 2). 
Table 2. Reversal phenomenon Detection

\begin{tabular}{|l|l|}
\hline Total number of observations & 28 \\
\hline Number of Winner-Loser phenomena & 10 \\
\hline Number of Loser-Winner phenomena & 07 \\
\hline Number of Loser-Loser phenomena & 07 \\
\hline Number of Winner-Winner phenomena & 04 \\
\hline Percentage & $60.7 \%$ \\
\hline
\end{tabular}

Following the detection of up to 60,7\% reversal phenomenon on the Tunis Stock market, we have to inquire about the generating causes of these irrational behaviors of financial assets such as: the risk effect; the size effect and the seasonal effect.

\subsection{The Risk Effect}

In this framework, we have to test whether the Winner-Winner phenomenon is explained by the difference in the risk level associated with the securities of each portfolio. The arbitrage portfolio is obtained according to the approach of Zaroin (1990) as follows:

$$
R_{A t}=R_{L t}-R_{W t}
$$

$R_{A t}$ is arbitrage portfolio return for the week $t, R_{L t}$ losers' returns for the week $t, R_{w t:}$ performance for the winners for week $t$. We determined in a first step portfolios returns $R_{a t}$, and in a second step, we determined the parameters of the following equation via Eviews8.0:

$$
\begin{aligned}
& R_{A t}=\delta_{A}+\beta_{A}\left(R_{m t}-R_{f t}\right)+\varepsilon_{A t} \\
& \mathrm{R}_{\mathrm{at}}=\gamma_{\mathrm{a}}+\beta_{\mathrm{a}}\left(\mathrm{R}_{\mathrm{mt}}-\mathrm{R}_{\mathrm{ft}}\right)+\psi_{\mathrm{at}}
\end{aligned}
$$

$\delta_{A}$ and $\beta_{A}$ are the equation parameters, $\mathrm{R}_{\mathrm{mt}}$ is the market performance for the week $\mathrm{t}, \mathrm{R}_{\mathrm{ft}}$ is the risk free rate (obtained from monetary market rates), $\varepsilon_{A t}$ is the residual term. Our results are reported in the following table:

Table 3. Detection of a possible risk effect on stock returns

\begin{tabular}{|c|c|c|c|c|c|c|c|}
\hline PF & $\delta_{A}$ & $\beta_{A}$ & $\begin{array}{c}\text { P-value } \\
\left(\mu_{2}\right)\end{array}$ & A & Constatation & $\begin{array}{c}\text { Risque } \\
\text { effect }\end{array}$ & Adjusted R-squared \\
\hline PF1 & -0.000623 & -0.268641 & 0.0309 & 0,05 & Significant & Présence & -0.000625 \\
\hline PF2 & 0.003616 & 0.133678 & 0.6274 & 0,05 & Non Significant & Absence & -0.002809 \\
\hline PF3 & -0.018807 & -0.317129 & 0.4829 & 0,05 & Non Significant & Absence & 0.015980 \\
\hline PF4 & -0.019286 & -0.322791 & 0.0757 & 0,05 & Non Significant & Absence & $-0,001494$ \\
\hline PF5 & -0.069057 & -1.328825 & 0.0599 & 0,05 & Non Significant & Absence & 0.024104 \\
\hline PF6 & -0.025510 & -0.394176 & 0.0824 & 0,05 & Non Significant & Absence & 0.017860 \\
\hline PF7 & 0.017251 & 0.319341 & 0.9570 & 0,05 & Non Significant & Absence & 0.048070 \\
\hline
\end{tabular}




\section{Macrothink}

Business and Economic Research

ISSN 2162-4860

2016, Vol. 6, No. 2

\begin{tabular}{|c|c|c|c|c|c|c|c|}
\hline PF8 & 0.036938 & 0.855555 & 0.0732 & 0,05 & Non Significant & Absence & 0.023286 \\
\hline PF9 & -0.018093 & -0.214810 & 0.4030 & 0,05 & Non Significant & Absence & 0.029093 \\
\hline PF10 & -0.016713 & -0.309933 & 0.0508 & 0,05 & Significant & Présence & 0.012770 \\
\hline PF11 & -0.045069 & -0.909559 & 0.1582 & 0,05 & Non Significant & Absence & 0.043854 \\
\hline PF12 & -0.018898 & -0.224729 & 0.6435 & 0,5 & Non Significant & Absence & 0.036512 \\
\hline PF13 & 0.009123 & 0.074725 & 0.6707 & 0,5 & Non Significant & Absence & 0.028260 \\
\hline PF14 & -0.009661 & -0.246516 & 0.2250 & 0,5 & Non Significant & Absence & 0.009705 \\
\hline
\end{tabular}

The adopted decision rule remains the same which involves:

If $\mathrm{P}$-value $\leq \alpha$ there is rejection of Ho hypothesis and then a risk effect existence.

If $\mathrm{P}$-value $\geq \alpha$ the null hypothesis is accepted, meaning an absence of risk effect.

Table 4. Risk effect presence on returns reversals

\begin{tabular}{|l|l|}
\hline Total number of observations & 14 \\
\hline Number of unfavorable observations & $\mathbf{2}$ \\
\hline Number of favorable observations & 12 \\
\hline Percentage & $14,28 \%$ \\
\hline
\end{tabular}

This result allows considering the existence such a linkage between the winner-loser effect and the level of risk only to the extent of $14.28 \%$. Consequently, this L- W phenomenon seems to be weakly generated by the risk of the securities composing portfolios, hence the need to look for other explanations for this phenomenon, such as the effect size.

\subsection{The Size Effect}

De Bondt and Thaler (1985) argue that there is a possible linkage relationship between the reversal phenomenon and the firm size since they observed that this phenomenon persists for small size firms. We follow the approach of Zaroin (1990) for the sake to test eventual size effect as follows: The firm size is determined from its capital value over the market that we calculated it using the following formula:

$$
V_{m t}=N_{t} \cdot C_{m t}
$$

$\mathrm{V}_{\mathrm{m}}$ : the value of capital market, $\mathrm{N}$ : number of securities issued on the market, $\mathrm{C}_{\mathrm{t}}$ : the price observed at time $\mathrm{t}$ on the market. Once the market capitalization is calculated, we proceed to the classification of these values in descending order. Our results are expressed in the following table:

Table 5. Portfolios distribution according to firm size

\begin{tabular}{|l|l|l|l|l|l|}
\hline $\begin{array}{l}\text { Winner } \\
\text { Portfolio }\end{array}$ & $\begin{array}{l}\text { Market } \\
\text { capitalization }\end{array}$ & $\begin{array}{l}\text { Firm } \\
\text { size }\end{array}$ & $\begin{array}{l}\text { Loser } \\
\text { Portfolio }\end{array}$ & $\begin{array}{l}\text { Market } \\
\text { capitalization }\end{array}$ & $\begin{array}{l}\text { Firm } \\
\text { size }\end{array}$ \\
\hline W11 & 102.010092 & Big & L7 & 81.460426 & Big \\
\hline W5 & 74.469660 & Big & L1 & 38.846008 & Big \\
\hline
\end{tabular}




\begin{tabular}{|l|l|l|l|l|l|}
\hline W8 & 56.462875 & Big & L13 & 37.373016 & Big \\
\hline W6 & 53.260941 & Big & L12 & 20.324949 & Big \\
\hline W10 & 42.761588 & Big & L10 & 16.585214 & Big \\
\hline W9 & 37.291744 & Big & L6 & 15.450290 & Big \\
\hline W7 & 20.906924 & Big & L8 & 11.795162 & Big \\
\hline W12 & 19.439445 & Small & L5 & 9.072808 & Small \\
\hline W1 & 16.940619 & Small & L2 & 7.666006 & Small \\
\hline W13 & 15.505738 & Small & L9 & 6.569773 & Small \\
\hline W2 & 14.072411 & Small & L4 & 6.126221 & Small \\
\hline W4 & 13.951523 & Small & L11 & 3.350295 & Small \\
\hline W3 & 12.400523 & Small & L3 & 1.408937 & Small \\
\hline W14 & 1.375275 & Small & L14 & 0.232828 & Small \\
\hline
\end{tabular}

Once determined the set of portfolios having small size, besides those with big one, we highlight solely the set of portfolios with a return reversal phenomenon and their respective sizes enabling to decide whether these return reversals concern only small size portfolio. The result of this comparison is shown in the following table:

Table 6. Detection of size effect on return reversals

\begin{tabular}{|l|l|l|l|l|}
\hline Portfolio & W /L & Phenomenon & Respective size & Observation \\
\hline \multirow{2}{*}{ PF1 } & W1 & WL & Small & Favorable \\
\cline { 2 - 5 } & L1 & LL & Big & Indecided \\
\hline \multirow{2}{*}{ PF2 } & W2 & WL & Small & Favorable \\
\cline { 2 - 5 } & L2 & LL & Small & Indecided \\
\hline \multirow{4}{*}{ PF3 } & W3 & WW & Small & Indecided \\
\cline { 2 - 5 } & L3 & LW & Small & Favorable \\
\hline \multirow{4}{*}{ PF5 } & W4 & WL & Small & Favorable \\
\cline { 2 - 5 } & L4 & LL & Small & Indecided \\
\cline { 2 - 5 } & L5 & LW & Big & Indecided \\
\hline PF6 & W6 & WL & Big & Favorable \\
\cline { 2 - 5 } & L6 & LL & Grande & Infavorable \\
\hline PF7 & W7 & WL & Grande & Unfavorable \\
\cline { 2 - 5 } & L7 & LW & Big & Unfavorable \\
\hline PF8 & W8 & WL & Big & Unfavorable \\
\cline { 2 - 5 } & L8 & LW & Big & Undecided \\
\hline \multirow{2}{*}{ PF9 } & W9 & WL & Big & Favorable \\
\cline { 2 - 5 } & L9 & LL & Small & Favorable \\
\hline PF10 & W10 & WL & Big & Unfavorable \\
\cline { 2 - 5 } & L10 & LL & Big & Undecided \\
\hline \multirow{3}{*}{ PF11 } & W11 & WL & Big & Unfavorable \\
\cline { 2 - 5 } & W11 & LW & Small & Favorable \\
\hline PF12 & W12 & WW & Small & Undecided \\
\hline
\end{tabular}




\begin{tabular}{|l|l|l|l|l|}
\hline & L12 & LW & Big & Unfavorable(8) \\
\hline \multirow{2}{*}{ PF13 } & W13 & WL & Small & Favorable (8) \\
\cline { 2 - 5 } & L13 & LL & Big & Undecided \\
\hline \multirow{2}{*}{ PF14 } & W14 & WW & Petite & Undecided \\
\cline { 2 - 5 } & L14 & LL & Petite & Undecided(12) \\
\hline
\end{tabular}

Table 7. Linkage relationship between size effect and return reversals

\begin{tabular}{|l|l|}
\hline Total number of observations & 28 \\
\hline Number of unfavorable observations & 08 \\
\hline Number of favorable observations (Small) & 08 \\
\hline Number undecided observations & 12 \\
\hline Percentage & $8 / 28=28,57(\%)$ \\
\hline
\end{tabular}

Owing to the findings displayed in table above, we consider that there is no a priori significant relationship tying Winner-Loser phenomenon and firm size since this phenomenon was detected for both small firms and large ones. Therefore, the firm size cannot explain this anomaly only in $28.57 \%$ of cases.

\subsection{The Seasonality Effect}

The existence of January effect hypothesis suggests that cumulative average residuals CAR of winner and loser portfolios during only this month appear to be higher than the generated CAR during the other months. In this context, we will take the portfolios that verify the existence of return reversal and do prove whether this anomaly is explained by January seasonality or not et ce by calculating the CAR average for the January month and then comparing it to those found during all other months together, using the Dummy variable (Dichotomous) which takes the value 1 in January and 0 if not.

Table 8. Detection of seasonality effect on return reversals

\begin{tabular}{|l|l|l|l|}
\hline Portfolio & Phenomenon & Test period & January effect \\
\hline \multirow{3}{*}{ PF1 } & WL & From $09 / 09 / 02$ to $17 / 05 / 03$ & Existence \\
\cline { 2 - 4 } & LL & From $09 / 09 / 02$ to $17 / 0503$ & Absence \\
\hline \multirow{2}{*}{ PF2 } & WL & From $19 / 05 / 03$ to $30 / 01 / 04$ & Existence \\
\cline { 2 - 4 } & LL & From $19 / 05 / 03$ to $30 / 01 / 04$ & Absence \\
\hline \multirow{2}{*}{ PF3 } & WW & From $02 / 02 / 04$ to $09 / 10 / 04$ & Existence \\
\cline { 2 - 4 } & LW & From $02 / 02 / 04$ to $09 / 10 / 04$ & Absence \\
\hline \multirow{2}{*}{ PF4 } & WL & From $11 / 10 / 04$ to $11 / 06 / 05$ & Existence \\
\cline { 2 - 4 } & LL & From $11 / 10 / 04$ to11/06/05 & Absence \\
\hline \multirow{2}{*}{ PF5 } & WW & From $13 / 06 / 05$ to $18 / 02 / 06$ & Absence \\
\cline { 2 - 4 } & LW & From $13 / 06 / 05$ to $18 / 02 / 06$ & Existence \\
\hline \multirow{2}{*}{ PF6 } & WL & From $20 / 02 / 06$ to $28 / 10 / 06$ & Absence \\
\cline { 2 - 4 } & LL & From $20 / 02 / 06$ to $28 / 10 / 06$ & Existence \\
\hline
\end{tabular}




\begin{tabular}{|l|l|l|l|}
\hline \multirow{3}{*}{ TPF7 } & WL & From $30 / 10 / 06$ to $07 / 06 / 07$ & Existence \\
\cline { 2 - 4 } & LW & From $30 / 10 / 06$ to $07 / 06 / 07$ & Existence \\
\hline \multirow{3}{*}{ PF8 } & WL & From $09 / 06 / 07$ to $15 / 03 / 08$ & Existence \\
\cline { 2 - 4 } & LW & From $09 / 06 / 07$ to $15 / 03 / 08$ & Existence \\
\hline \multirow{3}{*}{ PF10 } & WL & From $17 / 03 / 04$ to $22 / 11 / 08$ & Existence \\
\cline { 2 - 4 } & WL & From $17 / 03 / 04$ to $22 / 11 / 08$ & Absence \\
\cline { 2 - 4 } & LL & From $24 / 11 / 08$ to $01 / 08 / 09$ & Existence \\
\hline \multirow{3}{*}{ PF11 } & WL & From $24 / 11 / 08$ to $01 / 08 / 09$ & Absence \\
\cline { 2 - 4 } & LW & From $03 / 08 / 09$ to $17 / 04 / 10$ & Existence \\
\hline PF12 & WW & From $19 / 04 / 10$ to $25 / 12 / 10$ & Existence \\
\cline { 2 - 4 } & LW & From $19 / 04 / 10$ to $25 / 12 / 10$ & Absence \\
\hline PF13 & WL & From $27 / 10 / 10$ to $0 / 09 / 11$ & Existence \\
\cline { 2 - 4 } & LL & From $27 / 10 / 10$ to $03 / 09 / 11$ & Absence \\
\hline PF14 & WW & From $05 / 09 / 11$ to $12 / 05 / 12$ & Absence \\
\cline { 2 - 4 } & LL & From $05 / 09 / 11$ to $12 / 05 / 12$ & Absence \\
\hline
\end{tabular}

Table 9. Linkage relationship between seasonality and return reversals

\begin{tabular}{|l|l|}
\hline Total number of observations & 28 \\
\hline Number of unfavorable observations & 12 \\
\hline Number of favorable observations & 16 \\
\hline Percentage & $16 / 28=57,14 \%$ \\
\hline
\end{tabular}

The use of Dummy variable allowed us to achieve the following results:

Table 10. Detection of seasonality effect on return reversals

\begin{tabular}{|l|l|l|l|l|l|l|l|l|}
\hline Portfolio & W $/ \mathrm{L}$ & $\mu_{1}$ & $\mu_{2}$ & P-value & A & Constatation & Detection & adjusted R-squared \\
\hline \multirow{2}{*}{ PF1 } & W1 & 0.0061 & 0.010783 & 0.4203 & 0.1 & Not significant & Absence & 0.029831 \\
\cline { 2 - 9 } & L1 & 0.0105 & -0.002645 & 0.8125 & 0.1 & Not significant & Absence & 0.025910 \\
\hline \multirow{2}{*}{ PF2 } & W2 & -0.0011 & -0.006751 & 0.3535 & 0.1 & Not significant & Absence & 0.017051 \\
\cline { 2 - 9 } & L2 & 0.0037 & -0.021113 & 0.0353 & 0.1 & Significant & Presence & 0.024324 \\
\hline \multirow{2}{*}{ PF3 } & W3 & undec & Undecided & Undecid & 0.1 & undecided & undecided & Undecided \\
\cline { 2 - 9 } & L3 & undec & Undecided & Undecid & 0.1 & undecided & undecided & Undecided \\
\hline \multirow{3}{*}{ PF4 } & W4 & -0.0180 & 0.008116 & 0.6468 & 0.1 & Not significant & Absence & 0.038599 \\
\cline { 2 - 9 } & L4 & -0.0145 & 0.000685 & 0.9672 & 0.1 & Not significant & Absence & 0.037306 \\
\hline \multirow{2}{*}{ PF5 } & W5 & -0.0024 & -0.000463 & 0.9522 & 0.1 & Not significant & Absence & 0.017954 \\
\cline { 2 - 9 } & L5 & 0.0024 & -0.006514 & 0.4992 & 0.1 & Not significant & Absence & 0.022494 \\
\hline \multirow{2}{*}{ PF6 } & W6 & Indec & Indecided & Indecid & 0.1 & Indecided & Indecided & Indecided \\
\cline { 2 - 9 } & L6 & Indec & Indecided & Indecid & 0.1 & Indecided & Indecided & Indecided \\
\hline PF7 & W7 & -0.0014 & -0.007966 & 0.8243 & 0.1 & Not significant & Absence & -0.080267 \\
\cline { 2 - 8 } & L7 & 0.0037 & -0.019604 & 0.5971 & 0.1 & Non significant & Absence & 0.086404 \\
\hline
\end{tabular}




\section{$\triangle$ Macrothink}

Business and Economic Research

ISSN 2162-4860

2016, Vol. 6, No. 2

\begin{tabular}{|l|l|l|l|l|l|l|l|l|}
\hline \multirow{2}{*}{ PF8 } & W8 & 0.0135 & 0.0076 & 0.0501 & 0.1 & Significant & Presence & 0.024713 \\
\cline { 2 - 9 } & L8 & -0.0038 & -0.006770 & 0.4416 & 0.1 & Not significant & Absence & 0.020561 \\
\hline \multirow{2}{*}{ PF9 } & W9 & Indec & Indecided & Indecid & 0.1 & Indecided & Indecided & Indecided \\
\cline { 2 - 9 } & L9 & Indec & Indecided & Indecid & 0.1 & Indecided & Indecided & Indecided \\
\hline \multirow{3}{*}{ PF10 } & W10 & -0.0292 & 0.013699 & 0.03723 & 0.1 & Significant & Presence & 0.3892 \\
\cline { 2 - 9 } & L10 & -0.0228 & 0.006371 & 0.6715 & 0.1 & Not significant & Absence & 0.034859 \\
\hline \multirow{3}{*}{ PF11 } & W11 & -0.0346 & 0.025204 & 0.1467 & 0.1 & Non significatif & Absence & 0.040739 \\
\cline { 2 - 9 } & L11 & -0.0279 & 0.011307 & 0.5205 & 0.1 & Non significatif & Absence & 0.039256 \\
\hline \multirow{3}{*}{ PF12 } & W12 & Indecd & Indecided & Indecid & 0.1 & Indecided & Indecided & Indecided \\
\cline { 2 - 9 } & L12 & Indecd & Indecided & Indecid & 0.1 & Indecided & Indecided & Indecided \\
\hline \multirow{2}{*}{ PF13 } & W13 & -0.0135 & 0.013389 & 0.5788 & 0.1 & Not significant & Absence & 0.056204 \\
\cline { 2 - 8 } & L13 & -0.0118 & 0.016935 & 0.4708 & 0.1 & Not significant & Absence & 0.054841 \\
\hline \multirow{2}{*}{ PF14 } & W14 & -0.0118 & 0.004681 & 0.6874 & 0.1 & Not significant & Absence & 0.027014 \\
\cline { 2 - 8 } & L14 & -0.0063 & 0.012366 & 0.5498 & 0.1 & Not significant & Absence & 0.048204 \\
\hline
\end{tabular}

Table 11. Presence of January effect according to the explanatory variable D regression

\begin{tabular}{|l|l|}
\hline Total number of observations & 28 \\
\hline Number of unfavorable observations & 13 \\
\hline Number of favorable observations & 03 \\
\hline Number of undecided observations & 12 \\
\hline Percentage & $3 / 16=18.75 \%$ \\
\hline
\end{tabular}

Our results prove that seasonality effect contributes to explain this anomaly on Tunisian stock market (security trends reversal) only up to $18.75 \%$, which allows to rule on the fact that there are other fundamental anomalies that may cause such profits of momentum pattern.

\section{Conclusion}

Momentum or the relative continuity in stock returns corresponds to the tendency of securities that generated a good (bad) performance in the past to reproduce a good (bad) performance in the future. Jegadeesh and Titman (1993), Lewellen (2002) postulated that investment strategies, which involve buying securities with the best performing during the three to twelve months, and selling short securities that experienced the worst performance during the same period, are profitable and generate a return of about $1 \%$ per month for the next three - twelve months. Our empirical investigation has been based on a weekly database for a period from January 2002 to January 2013 concerning stock prices and the index values of Tunisian market.

Our results demonstrate the existence of winner-loser phenomenon for the selected period on the Tunis Stock Market, in accordance with the over-reaction hypothesis which states that portfolios with the worst past performance outperform, during subsequent periods, those having made good past performance and vice versa. Furthermore, we examined three possible 
factors that may explain reversals of portfolio returns such as risk, size and seasonality. Our results, in a first stage, show that only $20 \%$ of observations seem to be caused by the risk effect; and any change in firm size does exert an explanatory power of this phenomenon only in $30 \%$ of cases. As for seasonality or January effect, it appears significantly that portfolio returns were reversed to 55\% in January. Moreover, this result seems consistent with those of De Bondt \& Thaler (1987); Fama \& French (1986); Zarowin (1990) and May (1992) who refer this bias to the investor over-reaction phenomena and accordingly do not obey the Bayes theorem since they pay too much importance to new information at the expense of past ones. This irrational behavior of operators supports over-reaction as a trigger factor of return reversals.

\section{References}

Albert, F., \& Wang, N. (1998). Strategic trading, asymmetric information and heterogeneous prior beliefs. Journal of Financial intermediaries. 1(3-4), 271-294. http://dx.doi.org/10.1016/s1386-4181(97)00007-4

Alti, A. T., \& Lock P. C. (2014). Biased Beliefs, Asset Prices, and Investment: A Structural Approach. Journal of Finance. 69(1), 325-361. http://dx.doi.org/10.1111/jofi.12089

Asparouhova, E. Bessem, B. H., \& Kalcheva, I. (2013). Noisy prices and inference regarding returns. Journal of Finance. 68, 665-714. http://dx.doi.org/10.1111/jofi.12010

Baker, M., \& Wurgler, J. (2006). Investor Sentiment and the Cross-Section of Stock Returns. Journal of finance. 61(4), 1645-1679. http://dx.doi.org/10.1111/j.1540-6261.2006.00885.x

Barberis, N. Shleifer, A., \& Vishny, R. (1998). A model of investor sentiment. Journal of Financial. 49, 307-348. http://dx.doi.org/10.1016/S0304-405X(98)00027-0

Bazak, S., \& Makarov, D. (2014). Strategic Asset Allocation in Money Management. Journal of finance. 69(1), 179-217. http://dx.doi.org/10.1111/jofi.12106

Bertrand, M., \& Morse, A. (2012). Information Disclosure, cognitive Biases, and Payday Borrowing. Journal of finance. 66(6), 1865-1891. http://dx.doi.org/10.1111/j.1540-6261.2011.01698.x

Brockman, P. and Chung, D.Y (2000). An empirical investigation of trading an asymmetric information and heterogeneous prior beliefs. Journal of Empirical Finance. 7. 417-454. http://dx.doi.org/10.1016/S0927-5398(00)00020-7

Brown,G. W., \& Cliff, M. T. (2004). Investor sentiment and the near term stock market. Journal of Empirical Finance. 11, 1-27. http://dx.doi.org/10.1016/S0927-5398(04)00044-1

Buraschi, A., Trojani, F.. \& Vedolin, A. (2014). When Uncertainty Blows in the Orchard: Comovement and Equilibrium Volatility Risk Premia. Journal of Finance, 19, 101-137. http://dx.doi.org/10.1111/jofi.12095

Chan, I. Jegadeesh, K., \& Lakonishok, J. (1996). Momentum strategies. journal of Finance. 51, 1681-1713. http://dx.doi.org/10.1111/j.1540-6261.1996.tb05222.x 
Daniel, K, Hirshleifer, D., \& Subrahmanyan, A. (1998). Investor Psychology and security market under-Overreaction. Journal of Finance. 53, 1839-1886. http://dx.doi.org/10.1111/0022-1082.00077

DeBondt, W., \& Thaler, R. (1985). Does the Stock market Over react? Journal of Finance, 40(3), 793-808. http://dx.doi.org/10.1111/j.1540-6261.1985.tb05004.x

De Bondt, W. F. M., \& Thaler, R. (1987). Further evidence on investor overreaction and stock market seasonality. Journal of Finance. 42, 557-581. http://dx.doi.org/10.1111/j.1540-6261.1987.tb04569.x

De Long, N., Shleifer, B., Summers, F., and Waldman, C. (1990a). Noise trader risk in financial markets. Journal of Political Economy. 98, 703-738. http://dx.doi.org/10.1086/261703

De Long, N., Shleifer, B., Summers, F., \& Waldman, C. (1990b). Positive feedback investment strategies and destabilizing rational speculation. Journal of Finance. 45, http://dx.doi.org/10.2307/2328662

Durham,G. R., Hertzel, M. J., \& Spencer, J. M. (2005). The market impact of trends of sequences in performance: New Evidence.

Fama,E. (1998). Market efficiency, long terms returns and behavioral finance. Journal of Financial Economics.49.283-306. http://dx.doi.org/10.1016/S0304405X(98)00026-9

George, T., \& Huang, C. (2004). Week Hieg and Momentum investing. Journal of Finance, 59(5), 211-229. http://dx.doi.org/10.1111/j.1540-6261.2004.00695.x

Gervais, S. Heaton, J. B., \& Odean, T. (2011). Overconfidance, Compensation Contrasts, and $\begin{array}{lllll}\text { Capital Budgeting. Journal of finance. } 66, & 1735-1576 .\end{array}$ http://dx.doi.org/10.1111/j.1540-6261.2011.01686.x

Hirshleifer, D. (2001). Investor Psychology and Asset Pricing. Journal of Finance. 56, 1533-1597. http://dx.doi.org/10.1111/0022-1082.00379

Hong, H., \& Stein, J. C. (1999). A unified theory of under reaction momentum trading and overreaction in asset markets. Journal of Finance. 54, 21-43. http://dx.doi.org/10.1111/0022-1082.00184

Jegadeesh, N., \& Titman, S. (1993). Returns to Buying Winners and Selling Losers: Implications for Stock Market Efficiency. Journal of Finance. 48(1), 65-91. http://dx.doi.org/10.1111/j.1540-6261.1993.tb04702.x

Jegadeesh, N. and Titman, S. (2001a). Profitability of Momentum Strategies: An Evaluation of $\begin{array}{lllll}\text { Alternative Explanations. Journal of Finance. 56(2), } & \end{array}$ http://dx.doi.org/10.1111/0022-1082.00342

Jegadeesh, N., \& Titman,S. (2001b). Momentum. SSRN P45

Jegadeesh, N., \& Titman,S. (2002). Cross sectional and time series determinants of momentum 
returns. Review of Financial Studies. 15(1), 143-157. http://dx.doi.org/10.1093/rfs/15.1.143

Kahneman, D. et Tversky A. (1979). Prospect theory: an analysis of decision under risk. Economica. 47. (2), 263-292.http://dx.doi.org/10.2307/1914185

Kogan, L., Ross, S.A., wang, J., \& Westerfiled, M. M. (2006). The Price Impact And survival of Irrational Traders. Journal of finance, 61, 195-230. http://dx.doi.org/10.1111/j.1540-6261.2006.00834.x

Lee, C. M., Shleifer, A., \& Thaler, R. (1991). Investor sentiment and the closed end fund puzzle. Journal offinance, 46, 75-110. http://dx.doi.org/10.1111/j.15406261.1991.tb03746.x

Lewellen, J. (2002). Momentum and auto correction in stock returns. Review of financial studies, 15(2), 533-563. http://dx.doi.org/10.1093/rfs/15.2.533

Loewenstein, M., \& Willard, G. A. (2006). The limits of investor behavior. journal of finance. 61, 231-258. http://dx.doi.org/10.1111/j.1540-6261.2006.00835.x

Orlean, A. (1994). Bayesian Interactions and collective dynamics of opinion. Journal of $\begin{array}{llll}\text { Economics Behavior and 28 } & \text { Organization. }\end{array}$ http://dx.doi.org/10.1016/0167-2681(95)00035-6

Roewenhorst, K. G. (1998). International momentum strategies. Journal of Finance. 53(1), 267-284. http://dx.doi.org/10.1111/0022-1082.95722

Roewenhorst, K. G. (1999).Local return factors and turn over in emerging stock markets. Journal of Finance. 54(4), 1439-1464. http://dx.doi.org/10.1111/0022-1082.00151

Scherbina, A. (2004). Analyst disagreement, forecast Bias and Stock Returns. Harvard Business school working paper series N05. 2003 http://dx.doi.org/10.1086/261843

Shiller, R. J. (2000b). « Irrational Exuberance » Princeton UP ，Oxford.

Titman, S., \& Daniel, K. (2008). Market Reactions to Tangible and Intangible Information » Journal of finance, Vol LXI, 1605-1643

Tversky, A., \& Kahneman, D. (1974). Judgment under uncertainty: Heuristics and Biases. Science. 185(4157), 1124-1131. http://dx.doi.org/10.1126/science.185.4157.1124

Tversky, A., \& Kahneman, D. (1982). Judgment under uncertainty: heuristics and biases. Cambridge University Press, ISBN-13: 978-0521284141

Zhang, X. F. (2006). Information Uncertainty and Stock Returns. Journal of Finance, 61, 105-139. http://dx.doi.org/10.1111/j.1540-6261.2006.00831.x

Ziegler, A. (2001). Optimal portfolio Choice under heterogeneous beliefs. European Finance, Review, 4, 45-59. http://dx.doi.org/10.1111/j.1540-6261.2006.00831.x 


\section{Copyright Disclaimer}

Copyright for this article is retained by the author(s), with first publication rights granted to the journal.

This is an open-access article distributed under the terms and conditions of the Creative Commons Attribution license (http://creativecommons.org/licenses/by/3.0/). 